\title{
KADAR GLUKOSA DARI HIDROLISIS SELULOSA PADA ECENG GONDOK MENGGUNAKAN Trichoderma viride DENGAN VARIASI TEMPERATUR DAN WAKTU FERMENTASI
}

\author{
Purbowatiningrum R Sarjono*, Nies S Mulyani, Wirnia S Setyani \\ Universitas Diponegoro Semarang \\ Email: purbowatining@gmail.com
}

\begin{abstract}
ABSTRAK
Telah kita ketahui bahwa eceng gondok merupakan salah satu sumber selulosa yang melimpah di alam dan dapat dimanfaatkan sebagai sumber karbon bagi jamur Trichoderma viride. Eceng gondok memiliki bobot kering selulosa 21,5\%, hemiselulosa $33,9 \%$ dan lignin 7,01\%. Trichoderma viride adalah jamur saprofit yang berpotensi memproduksi selulase yang mampu mendegradasi ikatan $\beta$-1,4-glikosida pada rantai selulosa untuk menghasilkan glukosa. Glukosa dapat dimanfaatkan dalam produksi sirup gula, asam organik dan bioetanol. Penelitian ini bertujuan untuk mendapatkan Trichoderma viride yang mampu tumbuh pada media pertumbuhan hasil modifikasi eceng gondok serta memperoleh temperatur optimum aktivitas Trichoderma viride dalam menghidrolisis eceng gondok dan waktu fermentasi terbaik dalam menghasilkan glukosa.

Proses pertama adalah persiapan sampel enceng gondok meliputi delignifikasi, kurva pertumbuhan Trichoderma viride dibuat dalam media modifikasi eceng gondok untuk mengetahui waktu optimum pertumbuhan Trichoderma viride. Penentuan temperatur optimum dan waktu fermentasi terbaik dari aktivitas Trichoderma viride didasarkan pada glukosa yang dihasilkan dari hidrolisis selulosa pada eceng gondok menggunakan metode Nelson Somogyi.

Berdasarkan penelitian diperoleh hasil bahwa Trichoderma viride mampu tumbuh pada media modifikasi eceng gondok. Temperatur optimum aktivitas Trichoderma viride dalam menghidrolisis selulosa pada eceng gondok adalah $35^{\circ} \mathrm{C}$ dan waktu fermentasi terbaik dihasilkannya glukosa pada jam ke-96 yaitu sebesar 1,3864 mg/L.
\end{abstract}

Kata kunci: Trichoderma viride, eceng gondok, selulosa.

\section{GLUCOSE LEVELS FROM CELLULOSE HYDROLYSIS IN WATER HYACINT USE Trichoderma viride WITH VARIATION OF TEMPERATURE AND FERMENTATION TIME}

\begin{abstract}
As we know that water hyacinth is a the most abundance cellulose source in nature and can be used as carbon source for Trichoderma viride. Water hyacinth is containing cellulose $(21,5 \%)$, hemicellulose $(33,9 \%)$ and lignin $(7,01 \%)$. Trichoderma viride is saprofit fungi that have potention to produce cellulase that can degradation $\beta, 1$-4-glycoside bond in cellulose chains for producing glucose. Glucose can be utilized in produce sugar's syrup, organic acid and bioethanol. The experiment was aimed to get culture of Trichoderma viride that can growth in medium modification by water hyacinth and to determine optimum temperature of activity Trichoderma viride to produce cellulose to hydrolyzing water hyacinth and the best fermentation time to producing glucose. The first
\end{abstract}


process is the preparation of the sample, the growth curve of Trichoderma viride made in the modification media to determine the water hyacinth growth of Trichoderma viride optimum time. Determination of the optimum temperature and fermentation time best of Trichoderma viride activity based on glucose resulting from hydrolysis of cellulose in water hyacinth.

The result from the continuous adaptation of Trichoderma viride in medium modification by water hyacinth, it was obtained that Trichoderma viride can growth in $100 \%$ medium by water hyacint. The research result also showed that the activity test of Trichoderma viride to hydrolyzing cellulose in water hyacinth at temperature $35^{\circ} \mathrm{C}$ as optimum temperature for hydrolysis cellulose and fermentation time to produce glucose at 96 hours was $1,3864 \mathrm{mg} / \mathrm{L}$.

Keywords: Trichoderma viride, water hyacinth, selluloce.

\section{PENDAHULUAN}

Selulosa sebagai komponen utama dinding sel tumbuhan banyak di temukan di alam, yang merupakan polisakarida yang dapat dipakai sebagai sumber bioenergi yang hampir tidak pernah habis dan mudah diperbaharui (Ja'afaru dkk., 2010). Selulosa terdiri atas monomer glukosa yang dihubungkan dengan ikatan $\beta$-1,4-glikosida (Kamara dkk., 2006; Ramanathan dkk., 2010 dan Ja'afaru dkk., 2010). Dengan menghidrolisis ikatan glikosida dapat diperoleh glukosa yang kemudian diharapkan dapat digunakan untuk berbagai tujuan, seperti produksi sirup gula, asam organik (Cai Hao dkk., 2006) dan bioetanol (Kamara dkk.,2006).

Salah satu sumber selulosa yang mudah ditemukan dan melimpah di alam adalah eceng gondok. Tumbuhan ini merupakan rumput air yang memiliki kecepatan tumbuh yang tinggi (Deshpande dkk., 2008) sehingga dianggap sebagai gulma yang dapat merusak lingkungan perairan (Artati dkk., 2009). Dampak negatif yang ditimbulkan oleh eceng gondok antara lain menurunkan jumlah cahaya yang masuk ke dalam perairan sehingga menyebabkan turunnya tingkat kelarutan oksigen, menghambat aliran air, merusak sistem irigasi (Umsakul dkk., 2010), meningkatkan pertumbuhan nyamuk demam berdarah (Deshpande dkk., 2008) dan menurunkan estetika lingkungan (Artati dkk., 2009). Eceng gondok sering merugikan meskipun demikian dapat juga digunakan sebagai material produksi kertas, wine, kerajinan tangan dan biogas (Umsakul dkk., 2010). Eceng gondok dapat bermanfaat dalam bidang bioteknologi sebagai alternatif substrat lignoselulosa (Deshpande dkk., 2008) dan media pertumbuhan mikroorganisme. Eceng gondok mengandung bobot kering selulosa 21,50\%, hemiselulosa 33,90\% dan lignin 7,01\% (Deshpande dkk., 2008).

$\begin{array}{ccr}\text { Hidrolisis selulosa } & \text { secara } \\ \text { enzimatis dapat dilakukan dengan }\end{array}$ bantuan mikroorganisme selulolitik salah satunya adalah Trichoderma viride. Menurut Mandels (1982), Trichoderma viride merupakan kapang yang berpotensi memproduksi selulase dalam jumlah yang relatif banyak yang mampu mendegradasi ikatan $\beta$-1,4-glikosida pada selulosa untuk menghasilkan glukosa. Berdasarkan penelitian yang dilakukan Kamara dkk. (2006), Trichoderma viride mampu mendegradasi selulosa pada batang pisang dan menghasilkan glukosa dengan jumlah yang cukup tinggi sebesar $0,5676 \mathrm{mg} / \mathrm{mL}$.

Dalam melakukan aktivitasnya, Trichoderma viride sebagai penghasil 
enzim selulase dipengaruhi oleh faktor lingkungan seperti temperatur, $\mathrm{pH}$, adanya nutrien, agitasi dan waktu inkubasi. Pada saat Trichoderma viride menghidrolisis selulosa menjadi glukosa, terjadi reaksi enzimatis yang dipengaruhi oleh temperatur. Aktivitas Trichoderma viride juga dipengaruhi oleh waktu inkubasi yang merupakan waktu kontak antara enzim dengan substrat dalam membentuk produk, oleh karena itu diperlukan temperatur optimum dan waktu inkubasi yang paling tepat bagi suatu reaksi enzimatis untuk menghasilkan produk yang ditandai dengan adanya aktivitas yang tinggi dari produk glukosa yang dihasilkan. Substrat yang berbeda dapat mempengaruhi kondisi optimum dari aktivitas Trichoderma viride. Untuk mengetahui temperatur dan waktu inkubasi optimum aktivitas Trichoderma viride pada eceng gondok maka dilakukan uji aktivitas dengan range temperatur 30 sampai $60{ }^{\circ} \mathrm{C}$ dan waktu inkubasi 24 sampai 96 jam.

Pada penelitian ini dimaksudkan untuk memanfaatkan eceng gondok sebagai sumber karbon untuk pertumbuhan Trichoderma viride dan melakukan uji aktivitas Trichoderma viride dalam menghidrolisis eceng gondok untuk menghasilkan glukosa dengan variasi temperatur dan waktu fermentasi sehingga diperoleh data aktivitas berbagai temperatur dan waktu fermentasi dalam menghasilkan glukosa.

Tujuan penelitian ini adalah untuk memperoleh Trichoderma viride yang mampu tumbuh pada media pertumbuhan hasil modifikasi eceng gondok serta memperoleh data kadar glukosa dari variasi temperatur dan waktu fermentasi dari aktivitas Trichoderma viride dalam menghidrolisis selulosa dari eceng gondok.

\section{METODE PENELITIAN}

Penelitian ini dilakukan di Laboratorium Biokimia Jurusan Kimia FMIPA Universitas Diponegoro Semarang. Untuk mencapai tujuan penelitian dibagi menjadi beberapa tahapan meliputi delignifikasi eceng gondok, peremajaan Trichoderma viride, adaptasi Trichoderma viride ke media CMC (carboxymethy cellulose), adaptasi Trichoderma viride ke media eceng gondok, penentuan kurva pertumbuhan Trichoderma viride, uji aktivitas Trichoderma viride dalam menghidrolisis selulosa dengan variasi temperatur dan waktu inkubasi.

\section{Alat dan Bahan}

Alat-alat yang digunakan terdiri atas alat-alat gelas laboratorium kimia, lampu spirtus, autoklaf, penangas air, inkubator, mikropipet, alumunium foil, spektrofotometer UV-Vis, kuvet, sentrifus, neraca analitik, shaker, oven, kompor listrik, kertas label, $\mathrm{pH}$ stick, korek api, kertas saring, tabung reaksi, rak tabung reaksi, blender, pendingin, kapas, kain kasa, botol semprot dan pipet tetes.

Bahan-bahan yang dibutuhkan dalam percobaan ini meliputi biakan murni kapang Trichoderma viride TNCC6013, eceng gondok, aquades, media PDB (Potato Dextrose Broth), CMC (Carboxymethy cellulose) teknis, media PDB modifikasi dengan CMC, reagen Nelson Somogyi, buffer asetat $0,05 \mathrm{M} \mathrm{pH} 5$, reagen arsenomolibdat, $\mathrm{Ba}(\mathrm{OH})_{2} \quad 0,01 \mathrm{M}, \quad \mathrm{ZnSO}_{4} \quad 0,01 \mathrm{M}$ dan $\mathrm{NaOH}$ teknis.

\section{Prosedur Penelitian}

\section{Delignifikasi Eceng Gondok}

Delignifikasi dilakukan sebagai pretreatment terhadap eceng gondok untuk mengurangi kandungan lignin didalamnya. Eceng gondok yang sudah dikeringkan dilarutkan dengan larutan 
$\mathrm{NaOH}(\%$ w/v), kemudian dipanaskan pada suhu $90^{\circ} \mathrm{C}$ selama 3 jam (Hamisan dkk.,2009). Selanjutnya larutan disaring dengan kertas saring, residu larutan yang merupakan eceng gondok dicuci dengan aquades hingga $\mathrm{pH}$ residu netral. Eceng gondok dikeringkan di dalam oven dan diblender hingga berbentuk serbuk. Serbuk tersebut yang digunakan untuk uji selanjutnya.

\section{Peremajaan dan Pengadaptasian Trichoderma viride ke Media Modifikasi}

Sebanyak satu jarum ose kapang Trichoderma viride dari biakan induk ditempatkan secara aseptik pada $50 \mathrm{~mL}$ media PDB yang telah disterilkan dan dishaker pada suhu ruang selama 192 jam sampai kapang tumbuh. Kemudian sebanyak $1 \mathrm{~mL}$ inokulum kapang Trichoderma viride yang sudah tumbuh tersebut ditempatkan secara aseptik dan bertahap pada $50 \mathrm{~mL}$ media PDB modifikasi (antara CMC dengan kentang dan dekstrosa) yang telah disterilkan dan kemudian dishaker pada suhu ruang selama 192 jam sampai kapang tersebut tumbuh.

Tabel 1. Modifikasi media PDB dengan CMC

\begin{tabular}{|l|c|c|}
\hline $\begin{array}{c}\text { Adaptasi } \\
\text { Media }\end{array}$ & PDB (\%) & CMC (\%) \\
\hline PDB & 100 & 0 \\
\hline PDB I & 75 & 25 \\
\hline PDB II & 50 & 50 \\
\hline PDB III & 25 & 75 \\
\hline PDB IV & 0 & 100 \\
\hline
\end{tabular}

Selanjutnya sebanyak $1 \mathrm{~mL}$ kapang yang tumbuh pada media PDB IV ditempatkan secara aseptik dan bertahap pada $50 \mathrm{~mL}$ media substrat eceng gondok (CMC diganti dengan eceng gondok) yang telah disterilkan dan dishaker pada suhu ruang selama 192 jam sampai kapang tumbuh.
Tabel 2. Modifikasi media CMC dengan eceng gondok

\begin{tabular}{|l|c|c|}
\hline $\begin{array}{c}\text { Adaptasi } \\
\text { Media }\end{array}$ & CMC (\%) & $\begin{array}{c}\text { Eceng } \\
\text { Gondok (\%) }\end{array}$ \\
\hline CMC & 100 & 0 \\
\hline CMC I & 50 & 50 \\
\hline CMC II & 0 & 100 \\
\hline
\end{tabular}

\section{Pembuatan Kurva Pertumbuhan}

Sebanyak 28 buah erlenmeyer masing-masing diisi dengan $50 \mathrm{ml}$ media eceng gondok dalam buffer asetat $\mathrm{pH} 5$ kemudian disterilisasi dengan autoklaf selama 20 menit. Pada 12 buah erlenmeyer masing-masing ditambahkan $1 \mathrm{~mL}$ inokulum kapang Trichoderma viride (sebagai sampel) secara aseptik dan 12 buah erlenmeyer yang lain dijadikan sebagai kontrol. Kemudian ke24 erlenmeyer tersebut dishaker pada suhu ruang, selanjutnya sampel diambil tiap 24 jam sekali selama kurun waktu 288 jam untuk diukur berat keringnya. Penentuan pertumbuhan kapang Trichoderma viride dilakukan menggunakan metode pengukuran berat kering. Data yang didapatkan adalah jumlah berat kering yang diplotkan terhadap waktu sehingga akan diperoleh grafik jumlah berat kering vs waktu.

\section{Fermentasi Kapang Trichoderma viride pada Media Eceng Gondok dengan Variasi Temperatur dan Waktu Inkubasi}

Untuk menentukan pengaruh variasi temperatur pada aktivitas hidrolisis selulosa pada eceng gondok oleh kapang Trichoderma viride, diperlukan 7 buah erlenmeyer $250 \mathrm{~mL}$ yang berisi $50 \mathrm{~mL}$ media eceng gondok dalam buffer asetat $\mathrm{pH} 5$ yang sudah disterilkan. Diambil sebanyak $1 \mathrm{~mL}$ inokulum (dari stater) dan ditempatkan secara aseptik ke dalam masing-masing erlenmeyer tersebut. Kemudian semua erlenmeyer diinkubasi 
selama waktu tertentu (fase log dari kurva pertumbuhan). Untuk mengetahui temperatur optimum serta pengaruh temperatur terhadap aktivitas Trichoderma viride dalam menghidrolisis eceng gondok, maka erlenmeyer yang berisi inokulum diinkubasi pada temperatur yang bervariasi yaitu $30{ }^{\circ} \mathrm{C}$, $35{ }^{\circ} \mathrm{C}, 40{ }^{\circ} \mathrm{C}, 45{ }^{\circ} \mathrm{C}, 50{ }^{\circ} \mathrm{C}, 55{ }^{\circ} \mathrm{C}, 60{ }^{\circ} \mathrm{C}$ dan masing-masing dengan waktu inkubasi 24 sampai 96 jam, setelah itu dilakukan pengukuran kadar glukosa.

\section{Penentuan Aktivitas Trichoderma viride dalam Menghidrolisis Eceng Gondok Menghasilkan Glukosa dengan Metode Nelson-Somogyi.}

Setelah Erlenmeyer yang berisi inokulum diinkubasi pada temperatur yang bervariasi selama waktu tertentu, kemudian filtrat (media cair) diukur kandungan glukosanya (hasil hidrolisis eceng gondok oleh kapang Trichoderma viride). Selanjutnya disiapkan 7 buah tabung reaksi yang masing-masing diisi dengan $0,1 \mathrm{~mL}$ larutan inkubasi (media cair kapang) dari masing-masing hasil inkubasi dari perlakuan 4 kemudian larutan inkubasi diencerkan dengan aquades sampai volumenya menjadi 1,5 $\mathrm{ml}$ serta masing-masing tabung diisi dengan $0,2 \mathrm{ml} \mathrm{Ba}(\mathrm{OH})_{2} \quad 0,01 \mathrm{M}$ dan 0,2 $\mathrm{ml} \mathrm{ZnSO}_{4}$ 0,01M. Selanjutnya disentrifus selama 30 menit. Larutan hasil sentrifus diambil sebanyak $1 \mathrm{~mL}$ ditempatkan pada tabung reaksi kemudian ditambahkan dengan $1 \mathrm{~mL}$ larutan Nelson Somogyi, agar larutan dapat cepat bereaksi maka tabung reaksi yang berisi larutan dipanaskan di dalam air mendidih selama 15 menit, lalu didinginkan. Setelah itu dibubuhi $1 \mathrm{ml}$ reagen arsenomolibdat dan dibiarkan selama 1 menit. Larutan hasil yang berwarna hijau kebiruan diencerkan dengan aquades hingga volume menjadi $10 \mathrm{ml}$. Kemudian masing-masing tabung reaksi dilakukan pengukuran absorbansi pada panjang gelombang maksimum (754 $\mathrm{nm}$ ) dengan Spektrofotometer UV-Vis.
Kadar glukosa dapat ditentukan dari nilai absorbansi yang diperoleh dengan menggunakan kurva standar.

\section{HASIL DAN PEMBAHASAN}

\section{Delignifikasi Eceng Gondok}

Di alam selulosa tidak pernah ditemukan dalam keadaan murni melainkan berikatan dengan lignin dan hemiselulosa membentuk suatu lignoselulosa. Keberadaan lignin akan menghambat proses hidrolisis selulosa oleh enzim selulase karena lignin merupakan molekul kompleks yang terdiri atas unit-unit fenilpropana yang umumnya sulit didegradasi (Taherzadeh dan Karimi, 2008). Lignin membentuk ikatan yang kuat dengan selulosa sehingga memberikan bentuk yang kokoh pada dinding sel tanaman.

Lignin dapat dihilangkan atau dikurangi salah satunya dengan perlakuan alkali menggunakan $\mathrm{NaOH}$. Serbuk eceng gondok dilarutkan dengan larutan $\mathrm{NaOH}$ agar lignin dapat larut dan selulosa dapat mengendap. Selulosa mengendap pada kondisi alkali sehingga dengan penambahan $\mathrm{NaOH}$, selulosa akan mengendap (Richana dkk, 2007). Lignin dalam larutan $\mathrm{NaOH}$ akan membentuk senyawa fenolat yang larut dalam air. Senyawa fenolat terbentuk maka ikatan antara selulosa dengan lignin akan lepas sehingga diperoleh selulosa dalam keadaan bebas lignin. Eceng gondok hasil reaksi dengan $\mathrm{NaOH}$ dicuci dengan akuades hingga $\mathrm{pH}$ netral agar hasil tidak mempengaruhi proses selanjutnya.

\section{Peremajaan dan Pengadaptasian Trichoderma viride}

Pada penelitian ini Trichoderma viride akan digunakan untuk menghidrolisis selulosa dari eceng gondok, oleh karena itu Trichoderma viride diadaptasikan pada media hasil modifikasi dengan substrat eceng gondok. 
Media ini terdiri dari bahan-bahan yang dibutuhkan untuk pertumbuhan yaitu eceng gondok sebagai sumber karbon.

Langkah
pengadaptasian adalah pebelum Trichoderma viride yang dilakukan dengan menginokulasikan inokulum dari media agar PDA ke media cair PDB. Hal ini dilakukan agar Trichoderma viride aktif saat digunakan dan maksimal perannya pada proses selanjutnya. Pengadaptasian Trichoderma viride pada media pertumbuhan dilakukan secara bertahap. Media awal dari biakan murni Trichoderma viride adalah PDA sehingga adaptasi ke sumber karbon media pertumbuhan diawali dari media PDA ke media PDB, kemudian dilanjutkan ke media PDB modifikasi CMC untuk tahap adaptasi awal Trichoderma viride pada sumber karbonnya, yaitu kentang dan dektrosa ke CMC.

Trichoderma viride diadaptasikan ke media PDB yang dimodifikasi CMC bertujuan untuk mengadaptasikan Trichoderma viride pada media berselulosa seperti CMC sebelum digunakan ke media bersubstrat. Substrat yang digunakan adalah substrat dengan selulosa kompleks. Pada pengadaptasian ini akan diperoleh Trichoderma viride yang hanya menghasilkan enzim selulase, yang digunakan untuk menghidrolisis selulosa menjadi glukosa.

Trichoderma viride tumbuh pada media awal yaitu PDA yang komposisinya adalah kentang, dekstrosa dan air (Gandjar dkk., 1999). Kapang ini menggunakan kentang dan dekstrosa sebagai sumber karbon. Pada penelitian ini, agar kapang mampu menghidrolisis hanya selulosa maka adaptasi dilakukan dengan mengganti sumber karbon dari kentang dan dekstrosa dengan selulosa murni (CMC). Adaptasi dilakukan secara bertahap dengan cara mengurangi komposisi dari media awal (kentang dan dekstrosa) dengan CMC agar
Trichoderma viride dapat beradaptasi dengan mudah, sehingga ketergantungan pada kentang dan dekstrosa dapat dihilangkan. Dari hasil penelitian dapat diketahui bahwa pada berbagai variasi persentase sumber karbon dari media PDB modifikasi CMC, Trichoderma viride mampu tumbuh dengan baik. Trichoderma viride hanya mampu tumbuh sampai CMC 98\% dan PDB 2\% karena kemungkinan kapang ini masih membutuhkan nutrien dari media PDB.

Tahap perlakuan media pertumbuhan selanjutnya adalah media PDB modifikasi CMC ke media eceng gondok untuk adaptasi selanjutnya dari Trichoderma viride pada sumber karbonnya, yaitu CMC ke eceng gondok. Pengadaptasian ke media eceng gondok juga dilakukan secara bertahap agar memudahkan Trichoderma viride dalam beradaptasi.

Dari penelitian dapat diketahui bahwa pada media modifikasi eceng gondok, Trichoderma viride mampu tumbuh dengan baik, dengan kandungan eceng gondok $100 \%$.

\section{Pembuatan Kurva Pertumbuhan}

Kurva pertumbuhan merupakan
kurva yang menunjukkan fase pertumbuhan dari mikroorganisme dan pembuatannya bertujuan untuk mengetahui waktu panen paling baik untuk digunakan pada proses fermentasi. Pembuatan kurva pertumbuhan dilakukan dengan metode berat kering yaitu dengan menghitung pertambahan massa sel dari Trichoderma viride selama 288 jam. Trichoderma viride dalam media cair diambil setiap 24 jam untuk kemudian disaring dan dikeringkan lalu ditimbang massanya. Pada gambar 1 dibawah ini menunjukkan fase-fase pertumbuhan Trichoderma viride. 


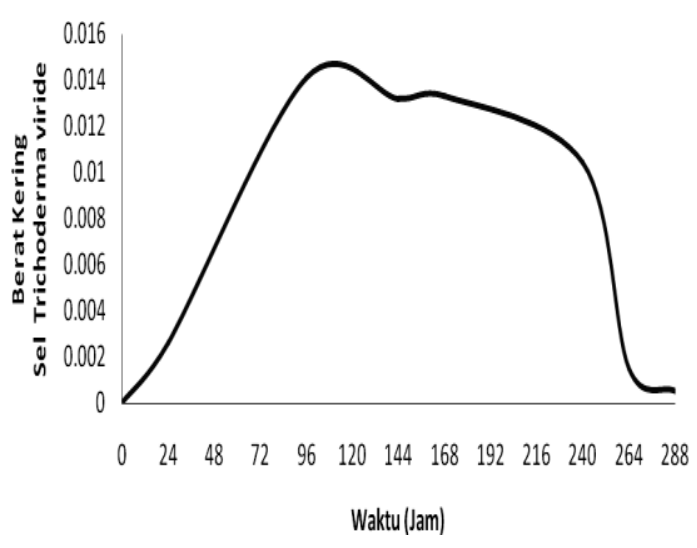

Gambar 1. Grafik Kurva Pertumbuhan Trichoderma viride

Dari data yang dihasilkan dapat diketahui bahwa waktu yang tepat untuk panen sel Trichoderma viride agar dapat digunakan untuk proses fermentasi selanjutnya yaitu pada jam ke-96 yang berada pada fase eksponensial. Pada fase ini pertumbuhan sel Trichoderma viride yang paling maksimal sehingga pada fase ini juga akan dihasilkan enzim selulase yang maksimal.

Uji aktivitas Trichoderma viride dalam menghidrolisis eceng gondok dengan variasi temperatur dan waktu inkubasi

Aktivitas Trichoderma viride didasarkan pada kemampuannya menghidrolisis selulosa menjadi glukosa dengan bantuan enzim selulase yang dihasilkannya. Enzim selulase bekerja dengan memutuskan ikatan $\beta-1,4-$ glikosida pada rantai selulosa. Enzim selulase yang dihasilkan oleh Trichoderma viride memiliki tiga komponen yaitu endo- $\beta$-1,4-glukanase, ekso- $\beta$-1,4-glukanase dan $\beta$-glukosidase (Juwaied, 2010). Dalam menghidrolisis selulosa, ketiga komponen selulase akan bekerja bersama-sama memecah ikatan selulosa menjadi unit-unit glukosa. Pada penelitian ini, glukosa yang dihasilkan diukur dan diuji dengan metode gula pereduksi menggunakan metode NelsonSomogyi .
Pada inkubasi jam ke-24, hampir semua dari variasi temperatur menunjukkan kadar glukosa yang tinggi dengan kisaran 0,6-1,1 mg/L. Data kadar glukosa pada jam ke-24 dapat dilihat pada gambar 2 .

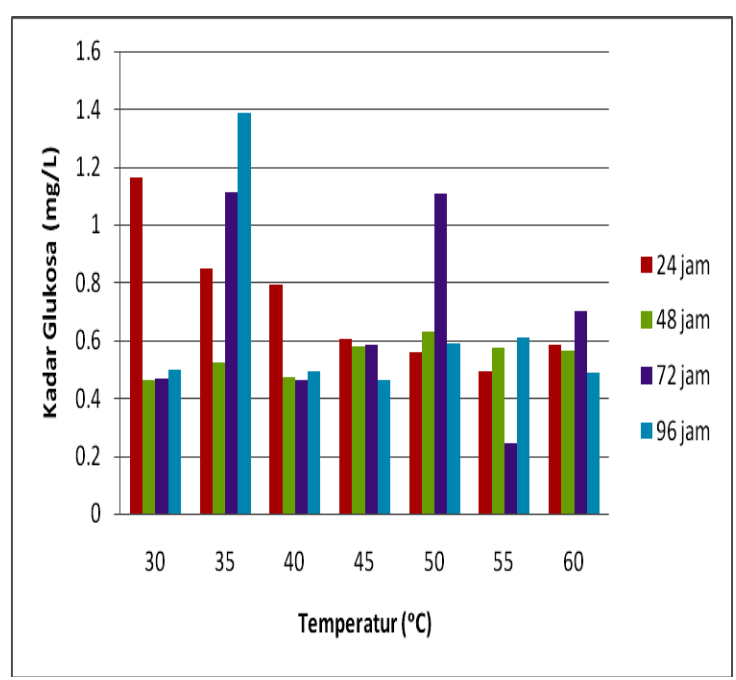

Gambar 2. Grafik Kadar Glukosa pada Berbagai Variasi Temperatur dan Waktu Fermentasi

Berdasarkan Gambar 2 terlihat bahwa pada inkubasi jam ke-24 tersebut selulase bekerja menghidrolisis selulosa sehingga menghasilkan glukosa, dengan glukosa yang tinggi maka dapat digunakan sebagai nutrisi sel Trichoderma viride untuk melakukan persiapan dalam proses pembelahan. Pada temperatur 30, 35, 40 dan $45{ }^{\circ} \mathrm{C}$ terukur kadar glukosa yang lebih tinggi dibandingkan pada temperatur 50, 55 dan $60{ }^{\circ} \mathrm{C}$ karena pada temperatur yang lebih tinggi kecepatan enzim dalam menghidrolisis menjadi berkurang.

Pada jam ke-48 temperatur 30, 35, 40, 45 dan $60{ }^{\circ} \mathrm{C}$ mengalami penurunan kadar glukosa sedangkan pada temperatur $50{ }^{\circ} \mathrm{C}$ dan $55{ }^{\circ} \mathrm{C}$ sedikit mengalami peningkatan kadar glukosa dari awal inkubasi.

Hal ini menunjukkan bahwa penurunan pada temperatur $30,35,40,45$ dan $60{ }^{\circ} \mathrm{C}$ ini disebabkan kapang 
Trichoderma viride menggunakan glukosa yang berasal dari hasil hidrolisis pada jam ke-24 sebagai sumber karbon untuk proses pembelahan sel.

Pada hari ketiga atau jam ke-72 terjadi peningkatan kadar glukosa pada tiap temperatur. Pada temperatur $35{ }^{\circ} \mathrm{C}$ dihasilkan kadar glukosa paling tinggi dibandingkan temperatur 30, 40, 45, 50, 55 dan $60{ }^{\circ} \mathrm{C}$.

Pada jam ke-72 ini sel Trichoderma viride telah melakukan pembelahan dan dihasilkannya enzim selulase yang aktif untuk menghidrolisis selulosa menjadi glukosa. Pada temperatur $35{ }^{\circ} \mathrm{C}$ menunjukkan kadar glukosa yang tinggi yaitu sebesar 1,1118 $\mathrm{mg} / \mathrm{L}$.

Pada inkubasi jam ke-96 dengan data kadar glukosa menunjukkan bahwa terjadi peningkatan kadar glukosa pada temperatur 30,35 dan $40{ }^{\circ} \mathrm{C}$. Pada temperatur $35{ }^{\circ} \mathrm{C}$, dihasilkan kadar glukosa yang paling tinggi dibandingkan temperatur lainnya yaitu sebesar 1,3864 $\mathrm{mg} / \mathrm{L}$.

Pada temperatur $35{ }^{\circ} \mathrm{C}$ telah menunjukkan kadar glukosa yang tinggi dari waktu inkubasi jam ke-72 hingga jam ke-96 sehingga temperatur ini merupakan temperatur optimum yaitu temperatur yang menyebabkan terjadinya reaksi kimia dengan kecepatan paling besar dan dihasilkan produk paling tinggi .

Berdasarkan pengamatan yang ditunjukkan dari Gambar 2 dapat disimpulkan bahwa temperatur optimum hidrolisis selulosa terdapat pada temperatur $35{ }^{\circ} \mathrm{C}$ yang memiliki kadar glukosa tertinggi pada inkubasi jam ke-96 yaitu sebesar 1,3864 mg/L. Pada temperatur $35{ }^{\circ} \mathrm{C}$ merupakan kondisi optimum terjadinya kompleks enzim substrat dan pada jam ke-96 merupakan waktu kontak antara selulase membentuk kompleks dengan selulosa.

\section{KESIMPULAN}

Berdasarkan hasil penelitian dan pembahasan yang telah dipaparkan sebelumnya, maka dapat disimpulkan bahwa eceng gondok dapat digunakan sebagai sumber karbon dalam media pertumbuhan Trichoderma viride serta aktivitas tertinggi Trichoderma viride dalam menghidrolisis selulosa dari eceng gondok pada temperatur optimum $35^{\circ} \mathrm{C}$ dan waktu fermentasi terbaik dihasilkannya glukosa pada jam ke-96 sebesar 1,3864 mg/ L.

\section{DAFTAR PUSTAKA}

Artati, E.K., Effendi, A., dan Haryanto, T., 2009, Pengaruh Konsentrasi Larutan Pemasak pada Proses Delignifikasi Eceng Gondok dengan Proses Organosolv, Ekuilibrium, 8(1), 25-28

Cai Hao, X., Bin Yu, X., dan Li Yan, Zhong., 2006, Optimization of The Medium for The Production of Cellulose by The Mutant Trichoderma reseei $\mathrm{WX}-112$ Using Response Surface Methodology, Food Technol. Biotechnol., 44(1), 89-94

Deshpande, S.K., Bhotmange, M.G., Chakrabarti, T., dan Shastri, P.N., 2008, Production of Cellulase and Xylanase by Trichoderma reesei (QM 9414 Mutant), Aspergillus niger and Mixed Culture by Solid State Fermentation (SSF) of Water Hyacinth (Eichhornia crassipes), Indian Journal of Chemical Technology, 15, 449-456

Gandjar, I., Robert, A.S., Kann, V.T.V., Ariyanti, O., dan Iman, S., 1999, Pengenalan Kapang Tropik Umum, Edisi ke-1, Yayasan Obor Indonesia, Jakarta 
Hamisan, A.F., Abd-Aziz, S., Kamaruddin, K., Shah, U.K., Shahab, N., dan Hassan, M.A., 2009, Delignification of Oil Palm Empty Fruit Bunch using Chemical and Microbial Pretreatment Methods, International Journal of Agricultural Research, 1-7

Ja'afaru, M.I., dan Fagade, O.E., 2010, Optimization Studies on Cellulase Enzyme Production by an Isolated Strain of Aspergillus niger YL 128, African Journal of Microbiology Research, 4(24), 2635-2639

Juwaied, A.A., Adnan, S., dan Al-Amiery, A.A.H.H., 2010, Production Cellulase by Different Co-Culture of Aspergillus niger and Trichoderma viride from Waste Paper, Journal of Yeast and Fungal Research, 1(6), 108-111

Kamara, D.S., Rachman, S.D., dan Gaffar, S., 2006, Degradasi Enzimatik Selulosa dari Batang Pohon Pisang untuk Produksi Enzim Selulase dari Kapang Trichoderma viride, Skripsi Fakultas Matematika dan Ilmu Pengetahuan Alam, Universitas Padjajaran, Bandung
Mandels, M., 1982, Cellulases, Vol.5, Academic Press, New York

Ramanathan, G., Banupriya, S., dan Abirami, D., 2010, Production and Optimization of Cellulase from Fusarium oxysporum by Submerged Fermentation, Journal of Scientific and Industrial Research, 69, 454-459

Richana, N., Irawadi, T.T., Nur, M.A., Sailah, I., Syamsu, K., dan Arkenan, Y., 2007, Ekstraksi Xilan dari Tongkol Jagung, J. Pascapanen, 4(1), 38-43

Somogyi, M., 1952, A New Reagent for Determination of Sugar, J. Biol. Chem, 200, 245

Taherzadeh, M.J., dan Karimi, K., 2007, Acid-Based Hydrolysis Processes for Ethanol from Lignocellulosic Materials : A Review, Bioresources, 2(3), 472-499

Umsakul, K., Dissara, Y., dan Srimuang, N., 2010, Chemical, Physical and Microbiological Changes during Composting of the Water Hyacinth, Pakistan Journal of Biological Sciences, 13(20), 985-992 